\title{
ACRL Board of Directors
}

Brief of Minutes

January 11, $1967-2: 00$ p.m.

Presknt: President Ralph E. McCoy; Vice President and President-Elect James Humphry, III; Past President Helen M. Brown; Director-at-Large Ruth M. Erlandson; Directors on ALA Council Elliott Hardaway, W. Carl Jackson, Rev. Jovian Lang, Kathryn R. Renfro, Edward B. Stanford; Chairmen of Sections John M. Dawson, Mary E. Schell, Lee Sutton; Vice Chairmen and Chairmen-Elect of Sections Stuart Forth, Mrs. Alice B. Griffith, Audrey North, Richard L. Snyder; Executive Secretary George M. Bailey, and Senior Secretary Rosemary Chamberlin.

Guests included: Mrs. Ruth M. Christensen, chairman of Audio-Visual Committee; Frances Kennedy, chairman of the Membership Committee; Theodore Samore, representative on ALA Ad Hoc Joint Committee on Cooperative Activities; James E. Skipper, executive secretary of ARL, and Robert L. Talmadge, chairman of LAD Statistics Committee for College and University Libraries.

Ralph E. McCoy presided.

(Note: Individual reports of ACRL activities were mailed to members of the Board and are available to ACRL members upon request. Wherever necessary, information from the reports will be added to the minutes.)

Members of the Board of Directors and guests introduced themselves.

The minutes of the Board of Directors' meeting as reported in ACRL News, September 1966, were approved.

$\mathrm{Mr}$. Bailey made various announcements of action to be taken at Midwinter, including scheduling of meetings for the San Francisco Conference and approval of schedules for program meetings for the Kansas City Conference. He asked that one report of the Midwinter meetings be left at the ACRL desk in New Orleans, to be used by the executive secretary for both Highlights and Proceedings.

Plans should be initiated for 1967/68. Committee appointments should be completed before the annual conference. Vice chairmen of sections and subsections should have their plans completed in the next six months.
Mr. Humphry reported the discussion and action of the Planning and Action Committee at its first meeting:

1. The Subject Specialists Section is continuing its correspondence with the chairman of the ALA Committee on Organization to secure division status. The earlier petition has not received favorable action, partly because of the cost of establishing a new division. The chairman of $\mathrm{COO}$ has suggested round table status as an alternative, but this was unacceptable to the officers of the section. The possibility of providing section status for the subsections does not provide as satisfactory a solution as would division status. Mr. Humphry prepared the following statement for discussion by the ACRL Board and transmission to $\mathrm{COO}$ :

The ACRL Board reaffirms its position with respect to supporting the Subject Specialists Section's petition for division status, in accordance with its action taken at the July 1966 Conference. The alternative to division status suggested by the Committee on Organization, that of a Round Table, is considered inappropriate because of lack of ALA staff liaison and because it does not adequately provide for the four Subsections. The Board feels that division status is the most appropriate solution and recommends retention of the Subject Specialists Section in its present status within ACRL only until approval of the petition is granted.

This statement was unanmiously approved by members of the ACRL Board of Directors present.

2. The Committee approved a resolution of the Agriculture and Biological Sciences Subsection, supporting the work of the National Agricultural Library in developing a coordinate network of biological and agricultural libraries.

3. Marion Milczewski, chairman of the ALA International Relations Committee, met with the Planning and Action Committee to discuss the desirability of establishing a formal liaison between ACRL and IRC. Academic librarians are represented in international activities. The ACRL office is used in these activities, and ARL is very much involved. An ACRL committee might explore what is being done and advise on future activities. Mr. McCoy and Mr. Milczewski were asked to prepare a statement recommending the establishment of such a 
committee, including a reference to funds for attendance of an ACRL representative at the IFLA meetings.

4. In regard to the proposal for an ALA Library Research Round Table, Mr. Harlow was asked to prepare a statement to reflect the thinking of the Planning and Action Committee for presentation to the Board.

5. E. J. Josey, chairman of the College Libraries Section's Committee on Community Use of Academic Libraries, reviewed the work of his committee, which has extended beyond the college library. Mr. Josey will ask his committee to consider its role for presentation to the ACRL Board of Directors.

6. The Planning and Action Committee will hold a two-day meeting on March 1415 at Rutgers University for the purpose of appraising the work of ACRL and planning for future activities.

James Skipper reviewed some ARL activities for the benefit of the members of the ACRL Board. Rutherford Rogers was elected chairman of ARL. Mr. Skipper will leave his position in ARL and accept a position

\section{A NEW book in Folletr's "designed}

\section{fOR STUdENTS"}

World-Wide

\section{fOREIGN LANGUAGE \\ diCTIONARY
SERIES \\ diCTIONARY
SERIES}

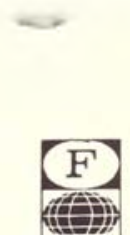

at Princeton University on April 1. Dues are being increased substantially to support ARL activities, which are being carried out by fifteen committees under the direction of a board. Some of the concerns are with a machine-readable inventory of world serials, foreign procurement of material from developing countries, non-GPO publications of the federal government, and library participation in indirect costs under federal grants. At the Midwinter meetings, the title of the ARL executive secretary was changed to executive director, and that of ARL chairman to president.

After President McCoy noted the extensive activities and achievements of Edmon Low in securing federal legislation for academic libraries, the Board unanimously approved the following resolution:

Resolved, that the Board of Directors of the Association of College and Research Libraries express deep appreciation to Edmon Low for his many years of distinguished service to the Association and for his significant contributions in promoting library development through his work on federal legislation.

Greater support of our Association is
Follett's World-Wide series, already includes: World-Wide Spanish / World-Wide German / World-Wide Italian / World-Wide French

\section{Follett Publishing Company}

1010 W. Washington Boulevard Chicago, Illinois 60607 
needed to assure continued funding of the Higher Education Act because of the loss of a number of our Congressional friends the last election, the death of Congressman John Fogarty of Rhode Island, and the high cost of the war. The Board members were asked to secure additional support in every way possible, and especially by making recommendations for (1) a person to fill the position of academic library specialist in the U.S. Office of Education, and (2) a person to fill the new position in the ALA Washington office for the implementation of federal library legislation. Both positions are crucial in the academic library world.

The guidelines for Title II A of the Higher Education Act should be available soon and will be sent directly to the presidents of academic institutions with an information copy to libraries. We hope to publish additional information in the February issue of ACRL News.

Andrew Eaton has resigned as a candidate for the office of vice president and president-elect of ACRL for 1967/68 because of his election as president-elect of ARI. The ACRL Appointments and Nominations Committee secured the acceptance of Arthur McAnally, University of Oklahoma library, to replace Mr. Eaton. (Note: After the Midwinter meetings, Mr. Eaton agreed to replace Mr. McAnally as a candidate for election to the ALA Council.)

Robert Talmadge reported that the $1965 / 66$ academic library statistics would be published in February. The LAD questionnaires were completed by 83 per cent of the institutions for the eighteen hundred forms mailed out. A grant of $\$ 9,600$ was received from USOE to support this program. The printout, being compiled at the University of Wisconsin-Milwaukee, should be ready by early February. Cost of the publication, in format similar to previous USOE publications, is expected to be approximately $\$ 3$. Approximately one thousand advance orders have been received. ACRL and ARL were requested to emphasize the importance of returning the completed forms immediately.

The 1964/65 statistics, collected by USOE, should be ready for publication by the end of January 1967, but there is some question whether they will be published because they are now considered out-ofdate. For the 1965/66 statistics, being collected by USOE, only thirteen hun- dred General Information Forms (GIF) have been returned, out of twenty-four hundred. A follow-up will be made and a note to this effect will be published in CRL News.

The ALA is working closely with USOE toward the implementation of plans for collecting statistics for all types of libraries.

The ACRL Board of Directors unanimously approved a resolution expressing appreciation to ALA, and especially to Al Trezza, Frank Schick, and Robert Talmadge, for their work in the collection of academic library statistics.

Mr. Samore distributed a preliminary draft of a "Statement on Interlibrary Cooperation," being developed by the interdivisional committee on this activity. Members of the Board will be asked for comments before a final statement is developed.

Mrs. Christensen reported on the meetings of the Audio-Visual Committee during Midwinter, introducing a resolution and support of federal funds for audio-visual uses. This was to be duplicated and distributed to members of the Board for action at its second meeting. The committee had accepted $\$ 500$ from the ALA AudioVisual Committec to help prepare a draft of guidelines for audio-visual services, which should be available for distribution at the San Francisco Conference.

The ACRL Membership Committee will be dissolved as of July 1967, according to Frances Kennedy, who has been serving as chairman. Appreciation was expressed to Miss Kennedy for her work with the committee. ACRL will continue to have a representative on the ALA Membership Committee. As of November 30, 1966, ACRL membership was 11,200 .

The meeting adjourned at 4:20 P.M.

\section{Brief of Minutes}

January 13, 1967-10:00 a.m.

Present: President Ralph E. McCoy; Vice President and President-Elect, James Humphry, III; Past President Helen M. Brown; Director-at-Large Ruth M. Erlandson; Directors on ALA Council Rev. Jovian Lang, Kathryn R. Renfro, Edward B. Stanford; Chairmen of Sections John M. Dawson, William H. Runge, Mary E. Schell, Lee Sutton; Vice Chairmen and ChairmenElect of Sections Stuart Forth, Mrs. Alice B. Griffith, Audrey North, Richard L. Snyder; Executive Secretary George M. Bailey, and Senior Secretary Rosemary Chamberlin. 
Guests included: Chairmen of Committees D. K. Berninghausen (reporting for Mrs. Patricia B. Knapp), Juliet B. Clark, Mark M. Gormley, Bernard Kreissman, John P. McDonald, Norman E. Tanis, R. Kent Wood; Chairman of Joint Committee Carl H. Sachtleben; Editors Peter M. Doiron, Felix Reichmann (reporting for Mrs. Margaret K. Toth); Chairman of CHOICE Editorial Board Sister Helen, and Chairmen of Subsections Roy L. Kidman and Jane Wilson.

Ralph E. McCoy presided.

Members of the Board and guests introduced themselves. At their second meeting, the members of the Planning and Action Committee discussed the following matters and made various recommendations to the Board:

1. Recommendations were made for strengthening the ALA Goals Award proposal, presented by the Junior College Libraries Section, for the establishment of a Junior College Library Information Center at ALA Headquarters, and staffed by a director, charged with the responsibility of collecting and disseminating information on all aspects of junior college library development, initiating and developing projects, and coordinating activities. The Junior College Libraries Section's representatives were asked to incorporate these suggestions before presenting the proposal to the Board of Directors. After some discussion, indicating the importance of providing strong ALA support for the needs of junior college libraries, the ACRL Board approved the revised proposal.

2. A suggestion was made by Norman Tanis, director of libraries, Kansas State College, Pittsburg, that each ACRL committee have one member of the Junior Members Round Table attached to it for a one year appointment. The following recommendation was made and approved by the Board:

It is recommended to the ACRL Board that a program of Intern Committee Membership be established on an experimental basis by authorizing the president-elect to appoint one extra junior member of the ACRL to standing committees for a one-year term, the candidates to be chosen if desired from a panel of nominees established by the president of the Junior Members Round Table. The Executive Secretary of ACRL is likewise authorized to negotiate the necessary arrangements with JMRT.

3. The Publications Committee proposed that subscription for College and Research
Libraries, to include ACRL News, be increased to $\$ 10.00$ per year for seventeen issues: six of the journal and eleven News issues. The increase is necessary to cover the rising costs of printing and postage. The Board approved the committee's recommendation that the increase be made.

4. In regard to the proposal for the establishment of an ALA Library Research Round Table, the committee proposed the following statement:

The ACRL Board of Directors recommends to the Committee on Organization that an ALA Library Research Round Table be established to provide an organizational base for an important professional function which is now being performed by a joint committee of the ALA Library Education Division and the Association of American Library Schools.

If an ALA Research Committee is in fact established with a relationship to the ALA Office of Research analogous to that of the International Relations Committee to the ALA International Relations Office, the Library Research Round Table would provide opportunities for public program paralleling those for which the International Relations Round Table is responsible.

\section{OTTO HARRASSOWITZ Library Agency WIESBADEN - GERMANY}

\author{
Direct service \\ on all German language \\ books and periodicals
}

Orders and inquiries are invited on both new and out-of-print material

Farmington Plan agent
or West and East Germany

$-$

For economy, speed, and accuracy you may rely upon your

German agent

OTTO HARRASSOWITZ 
This was approved.

5. The following statement was presented and approved by the Board:

The Planning and Action Committee recommends the creation of an International Relations Committee to be advisory to ACRL on ways in which the Association may be usefully involved in international library affairs, such committee to serve as a subcommittee of the ALA International Relations Committee.

6. The College Libraries Section, as a result of discussion and approval by the members of the Planning and Action Committee, developed the following resolution, which was approved by the Board:

Whereas it is recognized that the concerns of the College Libraries Section's Committee on Community Use of Academic Libraries Committee is shared by all other sections of the Association.

$B e$ it resolved that this Committee be instituted as a committee of ACRL.

Copies of the revision of the ALA Goals for Action statement had been distributed to members of the Board of Directors prior to Midwinter. John Dawson, a member of the ALA Executive Board, who served as chairman for the final revision, presented the statement for discussion, noting the activities in the development of the revision. The statement has been strengthened.

David Berninghausen, representing the Library Services Committee, recommended that the Goals should include a statement to read: "There should be programs to develop facility in the use of libraries on the part of students and faculty." Some discussion was held on the statement about the Library of Congress as the national library. With these comments and suggestions, the Board approved the adoption of the Goals for Action as revised.

Helen Brown reported on the meetings of the Program Evaluation and Budget Committee. The discussions were concerned with the role of various ALA units in international library activities.

Foster Mohrhart, President-Elect of ALA, met with PEBCO members to present tentative plans for his Kansas City Conference program, which he hopes will be a broad, flexible program, to make maximum use of the report of the President's National Commission on Libraries, due in November 1967. Douglas M. Knight, chairman of the Commission, might be invited to the mid-

\section{GRATIUS, Ortwin.}

Fasciculus rerum expetendarum et fugiendarum. London, 1690.

Very large, thick folio. 2 vols. 1480 pp.

With new introduction and bibliographical notes by Prof. V. Mudroch, Carleton University, Ottawa.

$A$ vast and indispensable work for the history of the Reformation and unorthodox opinion. The first edition of 1535 was compiled for use of a general council which never took place. This second edition by Edward Browne, the son of Sir Thomas Browne, is far larger, containing hundreds of texts of Hus, Wiclyf, Wideford, several Waldensiens, Erasmus, Hutten, Marsilius of Padua, Heymborg, Ryd, etc., a rich panorama of reform movement and thought preceding Luther, both English and continental. Particularly important are the texts of Wiclyf, Hus and their respective followers, including many anonymous sources. Included are some Catholic critics.

Prof. Mudroch's introduction and notes survey the sources of reformation history before Luther and indicate relations between these texts and other sources, published and manuscript. Wing G 1583.

\section{AUDAX PRESS, Dept. C}


winter 1968 meeting to discuss the report.

Ralph Blasingame, treasurer of ALA, presented an optimistic financial picture of ALA to the PEBCO members, emphasizing the increase in personal membership as an important factor. He recommended an additional long-range planning mechanism over and above the present capacities of PEBCO.

Units of ACRL were reminded to submit budget requests for $1967 / 68$ as soon as possible. The Appointments and Nominations Committee for $1967 / 68$, under the chairmanship of Ben Bowman, had completed its recommendations to $\mathrm{Mr}$. Humphry for appointments for next year and will complete its decisions regarding ACRL nominees for the 1968 elections in the near future.

John McDonald reported that the Advisory Committee on Cooperation with Educational and Professional Organizations plans to invite representatives of a dozen professional associations to meet with members of this committee at a luncheon in San Francisco. He reviewed the recent contacts with the representatives of the National Association of Student Personnel Administrators, noting their desire for advice about provision of library services to students outside of libraries on the campuses and for acquaintance with the problems of libraries. The Board approved the recommendation that preliminary planning meetings be held with representatives of NASPA, with the possible establishment of a joint committee of the two organizations. The executive secretary was asked to report ACRL's positive response to the members of NASPA.

The Committee on Library Services has agreed not to sponsor a preconference in Kansas City as originally announced, but to develop, instead, a conference program around the theme of special services to faculty and graduate students, with the possibility of securing cosponsorship from RSD and the Subject Specialists Section. They also hope to consider how special libraries can augment the services of academic libraries. A future preconference might be concerned with the relations of campus groups to the library and the role of the library in improving the instructional process.

The Committee on Local Arrangements, with Juliet Clark as chairman, had met to plan schedules for the ACRL booth in San Francisco and would be pleased to be of service to other ACRL units in making an arrangement. 


\section{\}The most important reference work on modern China since World War II}

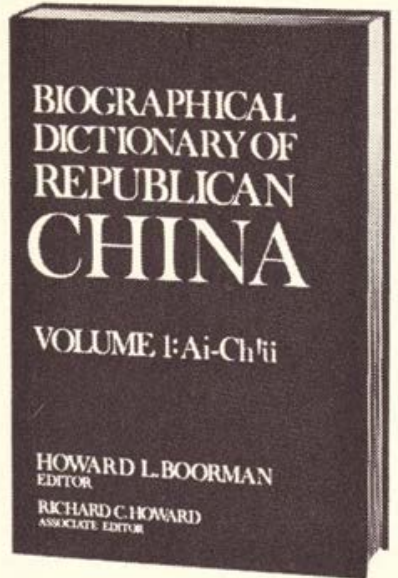

This first volume of a projected five-volume work contains 150 detailed biographical articles on persons living and dead who were important during the republican period (1911-49) in China, including Chiang Kai-shek and Chou En-lai. In addition to political and military leaders, there are biographies of individuals prominent in diplomacy, business and banking, literature, the arts, scholarship, social reform, education, the press and publishing, science, religion, aviation, medicine, and other fields.

Over ten years in preparation, the Biographical Dictionary of Republican China will, when completed, provide a massive reference work, at once systematic and comprehensive, for all organizations, libraries, and individuals concerned with twentiethcentury China. Volume I includes a preface by the general editor, explanatory notes, and a complete listing of all contributors. $\$ 20.00$ ( $A$ brochure detailing subscription plans for the entire set will soon be available.)

\section{COLUMBIA UNIVERSITY PRESS}

440 West 110 th Street

New York, N.Y. 10025
The National Library Week Committee is making final plans for a brochure on junior college libraries, to be distributed by March 1, and hopes to receive a donation of $\$ 2,000$ in support of its development. Thirty thousand copies will be distributed to administrators of institutions which might be in the planning stage, but, more important, to the many groups which use the graduates of junior colleges.

The Ad Hoc Committee on Relations with ARL met with the Standards Committee to consider the need for standards for university libraries, noting the importance of the subject to both ACRL and ARL, and the hope for continued joint concern. The committee also concerned itself with possibilities of scheduling meetings of the two associations closer together during conferences. ARL meetings are always scheduled on the weekend prior to the ALA meetings. When ACRL meetings are scheduled late in the conference week, it is difficult for ARL members to remain for both sets of meetings.

The ALA Ad Hoc Committee on Research has dissolved itself. It had been formed to serve as a liaison with federal groups concerned with libraries and information centers, and the work was concluded with the establishment of the Ad Hoc Joint Committee on National Library and Information Systems. Appreciation was expressed to Maurice Tauber and his committee for their work.

Norman Tanis, chairman of the Standards Committee, reported that the "Guidelines for Library Service to Extension Students" had been published in the January 1967 ALA Bulletin. He hopes for formal endorsement by other associations. The ALA Standards for College Libraries are now outdated and need to be considered for possible revision. The Committee met with representatives of ARL to consider the possibility of standards for university libraries and hopes to hold another joint meeting on the subject. The subcommittee to revise the ALA Standards for Junior College Libraries decided that new guidelines would be helpful and hopes to have a working document by July 1967. A meeting on the subject is being planned for the AAJC conference in San Francisco early in March.

The ACRL representatives of the AACACRL Committee on College Libraries met to explore the recommendations that a newsletter be developed for college presi- 
dents. Carl Sachtleben, chairman, stated that several papers would be written on the subjects of cooperative programs, microtexts, and, possibly automation, for the information of administrators. A meeting of the joint committee is being planned for April 1967. Members of the Board were asked for suggestions of topics for discussion by the committee.

CHOICE will include the editorial title on its front cover in the future. Peter Doiron, Editor, has been asked by the Editorial Board to investigate the possibility of publishing CHOICE reviews on cards; to publish the "Opening Day Collection," which appeared in the September-December 1965 issues, as a separate reprint as soon as possible; and finally to investigate the publication of supplements on a twoor three-year basis. Sister Helen, chairman of the Editorial Board, expressed appreciation to $\mathrm{Mr}$. Doiron and his staff for their fine job with CHOICE.

Helen Brown presented the following resolution, which was approved by the Board to be included in a letter from President McCoy to Verner Clapp:

Whereas the Council on Library Resources has provided a second subsidy of $\$ 108,855$ to provide for the continuing publication of CHOICE, be it resolved that the Board of Directors of the Association of College and Research Libraries expresses its deep gratitude to the Council on Library Resources for the generous and timely support.

Felix Reichmann, reporting for the ACRL Microcard Series, recommended that changes in technology and in the field of librarianship necessitated consideration of changes in the Series:

1. Technology-a change from microcards to microfiche.

2. Content-because of the lack of masters theses, the Series should consider annual reports of libraries, acquisitions policy statements, surveys, library department manuals, and reports of ALA divisions.

The College Libraries Section's Committee on Non-Western Resources is making plans for a preconference in Kansas City.

Mrs. Alice Griffith, vice chairman of the Junior College Libraries Section, reported the receipt of a grant of $\$ 5,000$ from the ACRL Committee on Grants to develop a proposal for demonstration libraries in junior colleges, and the plans for a preconference at UCLA, June 21-24.

The Rare Books Section is planning a

\section{CUSHING-MALLOY, ING.}

1350 North Main Street P.O. Box 632

Ann Arbor, Micbigan 48107

Printers of Who's Who in Library Service LITHOPRINTERS

Known for

QUALITY_ECONOMY_SERVICE

Let us quote on your next printing 


\section{TROUBLE-}

\section{MAKERS?}

For the all-knowing, confident Bible reader who has made up his mind and does not want to be confused with intricate details, these two biblical references are trouble-makers. But for the serious scholar or student of the Bible, these 16 volumes are an endless source of information.

The Interpreter's Bible features both RSV and King James Version of the Bible, side by side for easy comparison; an exegesis; an exposition; and other features. Single volumes, $\$ 8.75$; 12-volume set, $\$ 89.50$. Deluxe leather edition (12-vol. set) $\$ 199.50$.

"Material on the study of the Bible which surpasses in scholarly competence. completeness, and clarity the contents of many a three-year theological seminary course."-The Christian Century

The Interpreter's Dictionary of the Bible is an illustrated encyclopedia that defines and explains every person named in the Bible or Apocrypha; every town and region. hill and stream; every plant, animal, and mineral; every object used in daily life; and major biblical doctrines and theological concepts. More than 1,000 blackand-white illustrations and 56 pages of full-color photographs and maps. The 4volume set, $\$ 45$.

*. as a news event in American Bible publishing in recent years, ranks second only to the production of the RSV itself . . our first word in this instance must be one of gratitude to Abingdon for quietly and patiently serving as steward of the growing body of scholarly material in recent years, and publishing it first in The Interpreter's Bible and now in the Dictionary."-The Christian Century

\section{A BINGDON PRESS}

Nashville New York preconference on the subject, "Techniques of Special Collections," to be held at Stanford, June 22-23. No joint meeting is being planned with the Bibliographical Society of America this year.

The following resolution, introduced by the Audio-Visual Committee at the first Board meeting was approved:

The ACRL Audio-Visual Committee, noting the great opportunity afforded colleges and universities to build desirable and useful A-V centers with funds granted through the Higher Education Act of 1965, and particularly under Title II and Title VI;

And recognizing the great need for $A-V$ materials and equipment as an integral part of the services of a large number of colleges and university libraries;

The Committee recommends that the officials of ACRL go on record as endorsing the request and expenditure of funds for these purposes;

And that the ACRL endorse the principle of Federal Funds for Higher Education to provide continued upgrading and encouragement by Congress of libraries through continued attention to these needs.

The meeting was adjourned at 12:20 P.M.

\section{FEDERAL LEGISLATION 1968 BUDGET}

President Johnson's 1968 Federal Budget includes the following requests for academic library purposes. (Refer to the Washington Newsletter for additional information regarding budget requests.)

Higher Education Act of 1965

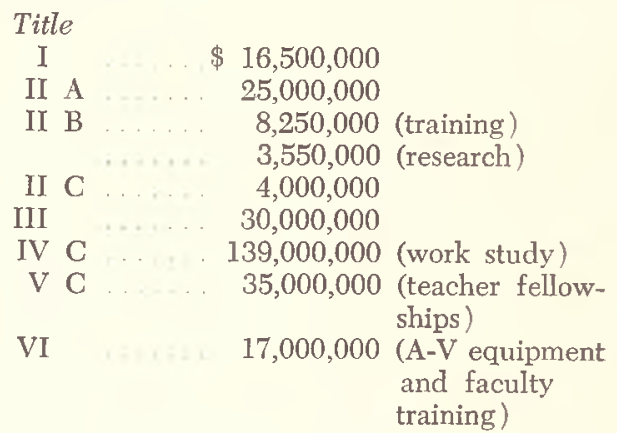

Higher Education Facilities Act
I

II

$$
\begin{array}{cc}
390,000,000 & \begin{array}{l}
\text { (graduate con- } \\
\text { struction) }
\end{array} \\
50,000,000 & \begin{array}{l}
\text { (undergraduate } \\
\text { construction) }
\end{array}
\end{array}
$$

Library Services and Construction Act 